\title{
Analysis of Tie2 function in mast cells
}

\author{
Alison Hirukawa*, D James Haddon, Frann Antignano, Michael R Hughes, Kelly M McNagny \\ From AllerGen NCE Inc.'s Fifth Annual Research Conference: Innovation from Cell to Society \\ Québec City, QC, Canada. 7-9 February 2010
}

\section{Background}

Mast cells are most widely acknowledged as a central mediator of allergic reactions. Recent literature has also implicated mast cells in a variety of biological and pathological conditions, spurring an interest in the genetic regulation of mast cell function and development. In a survey of global gene expression, we identified higher Tie2 mRNA expression in bone marrow derived mast cells (BMMC) in relation to a Lin ${ }^{-} \mathrm{Sca} 1$ ${ }^{+} \mathrm{CKit}^{+}$(LSK) bone marrow population. Tie2 (gene name $T e k)$ is a receptor tyrosine kinase more commonly known for its expression on endothelial cells and a receptor for angiopoietins including Ang1 and 2. Our objective is to explore the function of $\mathrm{Tie} 2$ in mast cell development and biology.

\section{Materials and methods}

The mRNA level of Tie2 in of BMMC were established via a microarray and confirmed at the protein level through FACS and Western Blot. Mature BMMC were stimulated with Ang1 (200 ng/ml) and probed for phospho-Akt and phospho-Erk. Tie-2 deficient mast cells were derived from $\mathrm{Tie}^{-/-}$and $\mathrm{Tie}^{+/-}$embryonic stem (ES) cells, as reported previously [1]. Briefly, embryoid bodies were generated from ES cells and incubated for 14 days, after which the embryoid bodies were dissociated into single cell suspensions and grown in media containing SCF and IL-3.

\section{Results}

BMMC express Tie 2 mRNA and Tie 2 protein at the membrane surface; to our knowledge, this is the first report of Tie 2 protein expression in mast cells. Functional analysis and intracellular signaling response following stimulation with Tie2 ligands has revealed that Tie2 is a functionally active Ang1 receptor, as evidenced by activation of Akt and Erk. ES cell derived mast cells

\footnotetext{
The Biomedical Research Centre, The University of British Columbia,
} Vancouver, British Columbia, V6T 1Z3, Canada
(ESMC) can be derived from Tie2 $2^{-/-}$and $\mathrm{Tie}^{+/-}$ES cell lines, and these ESMC do not possess any observable morphological abnormalities.

\section{Conclusions}

Given the importance of mast cells in the pathology of human disease, analysis of novel genetic factors regulating mast cell function and development may provide insight into suitable therapeutic targets. To further explore the role of Tie2 in mast cells, future aims include evaluating the ability of Tie ${ }^{-1-}$ ESMC to reconstitute mast cell-deficient mouse models (eg, Kit ${ }^{W / W v}$ ) and in vitro assays of Tie $2^{-/-}$ESMC function such as degranulation and migration.

Published: 26 November 2010

Reference

1. Tsai M, Tam SY, Wedemeyer J, Galli SJ: Mast cells derived from embryonic stem cells: a model system for studying the effects of genetic manipulations on mast cell development, phenotype, and function in vitro and in vivo. Int J Hematol 2002, 75:345-9.

doi:10.1186/1710-1492-6-S3-P16

Cite this article as: Hirukawa et al:: Analysis of Tie2 function in mast cells. Allergy, Asthma \& Clinical Immunology 2010 6(Suppl 3):P16.

Submit your next manuscript to BioMed Central and take full advantage of:

- Convenient online submission

- Thorough peer review

- No space constraints or color figure charges

- Immediate publication on acceptance

- Inclusion in PubMed, CAS, Scopus and Google Scholar

- Research which is freely available for redistribution 